Hope College

Hope College Digital Commons

Faculty Publications

$11-18-2019$

\title{
Zheng $\mathrm{He}$ and the American Liberal Arts Education: Contexts and Complications
}

Marla Lunderberg

Hope College, lunderberg@hope.edu

Follow this and additional works at: https://digitalcommons.hope.edu/faculty_publications

Part of the Asian History Commons, and the Chinese Studies Commons

\section{Recommended Citation}

Repository citation: Lunderberg, Marla, "Zheng He and the American Liberal Arts Education: Contexts and Complications" (2019). Faculty Publications. Paper 1482.

https://digitalcommons.hope.edu/faculty_publications/1482

Published in: International Communication of Chinese Culture, Volume 6, November 18, 2019, pages 295-310. Copyright (C) 2019 Springer.

This Article is brought to you for free and open access by Hope College Digital Commons. It has been accepted for inclusion in Faculty Publications by an authorized administrator of Hope College Digital Commons. For more information, please contact digitalcommons@hope.edu. 
Zheng He and the American Liberal Arts Education:

Contexts and Complications

\author{
Marla Lunderberg \\ Associate Professor of English \\ Hope College
}

Marla Lunderberg

Lubbers Hall \#307

126 East $10^{\text {th }}$ Street

Holland, MI 49423-3516

lunderberg@hope.edu

(USA phone \#) (616) 634-3183 


\begin{abstract}
Zheng He was a eunuch of Moslem family heritage who held great authority early in the Ming Dynasty, primarily under the Yongle emperor (reign: 1402-24), as he led seven maritime expeditions, of which three reached the eastern coast of Africa. Of recent English language projects on Zheng He, Henry Tsai (1996) explores the context of the eunuchs of the Ming Dynasty in defining Zheng He's work, and Edward Dreyer (2007) and Timothy Brook (2010) portray Zheng He within the context of the Chinese tributary system. However, other images also hold power over the Western imagination: Louise Levathes (1994) portrays Zheng He's travels as trade missions and Gavin Menzies's popularized Zheng He (2002) is first and foremost an explorer designed to be compared to Western explorers. While Zheng He can be partially understood through comparison to fifteenth-century Western navigators, we limit our knowledge when we identify him and his expeditions through the lens of Western traders and explorers. It is important instead to identify Zheng He within the framework of fifteenth-century Chinese history and culture. An examination of resources and methods for teaching Zheng He in an undergraduate liberal arts curriculum can serve as a case study for important issues to consider when infusing Asian Studies into undergraduate studies.
\end{abstract}

\title{
KEYWORDS
}

\#ZhengHe \#MingDynasty \#China \#TributarySystem \#Eunuch \#Columbus \#VascodeGama 
Zheng He and the American Liberal Arts Education: Contexts and Complications

English-language references to Zheng He have increased exponentially in the two decades since Louise Levathes published When China Ruled the Seas: The Treasure Fleet of the Dragon Throne, 1405-1433 (Oxford, 1994). ${ }^{1}$ Nonetheless, in the U.S., a preliminary search for "Zheng He" — either through academic databases or popular internet sites—indicates that many writers, both scholarly and popular, locate this historic figure by titling him "the Chinese Columbus" or alternately, "the Vasco da Gama of China."” While Zheng He can be partially understood through comparison to fifteenth-century Western navigators, our knowledge is not just incomplete, but incorrect, when we identify him and his expeditions through the lens of Western traders and explorers. It is important instead to identify Zheng He within the framework of fifteenth-century Chinese history and culture, whether this be through a focus on the role of eunuchs in China, or on the traditional authoritative voice of Confucian scholars in establishing Chinese historical narrative, or on the structure of the tribute system in the Ming Dynasty. An examination of resources and methods for teaching Zheng He in an undergraduate liberal arts curriculum can serve as a case study for important issues to consider when infusing Asian Studies into undergraduate studies.

\section{Identities Imposed on Zheng He (and Why They Matter)}

Zheng He was a eunuch of Moslem family heritage who held great authority early in the Ming Dynasty, primarily under the Yongle emperor (reign: 1402-24). Of the seven maritime expeditions led by Zheng He, three (the fifth, sixth and seventh) reached the eastern coast of

\footnotetext{
${ }^{1}$ My focus in this article is on English-language resources, although I do take into consideration other resources when they are available in translation or are mentioned in English-language articles.

${ }^{2}$ See, for example, Robert Finley's critique of scholars who do so, in his review of Levathes in Sixteenth Century Journal (1997). For a popular account that draws this comparison, see John Green, "Crash Course: World History \#21, Columbus, da Gama and Zheng He! $15^{\text {th }}$ Century Mariners."
} 
Africa. $^{3}$ As they recount the details of Zheng He's life and accomplishments, the shape of many scholars' arguments tells us more about the scholars themselves than about Zheng He or Ming China. Of recent English language projects on Zheng He, Henry Tsai (1996) explores the context of the eunuchs of the Ming Dynasty in defining Zheng He's work, and Edward Dreyer (2007) and Timothy Brook (2010) portray Zheng He within the context of the Chinese tributary system, but other images also hold power over the Western imagination: Louise Levathes (1994) portrays Zheng He's travels as trade missions and Gavin Menzies's popularized Zheng He (2002) is first and foremost an explorer designed to be compared to Western explorers. The details of life in fifteenth-century China that enrich Levathes's and Menzies's books tend to paint a portrait of an "exotic other,"4 and so the Zheng He of these books remains forged through early modern European paradigms. By contrast, Tsai, Dreyer and Brook guide their readers in resisting reliance on dominant Western paradigms, instead carefully marking the differences between fifteenth century China and the modern Western world. ${ }^{5}$ Thus, among these writers, Tsai, Dreyer and Brook provide the best examples of scholarship that avoids the trap of defining China through overly simplistic comparisons to the West.

\section{Zheng He as Trader}

With its portrayal of Zheng He as a trader, Louise Levathes's 1994 book, When China Ruled the Seas: The Treasure Fleet of the Dragon Throne, 1405-1433, opened the topic of Zheng

\footnotetext{
${ }^{3}$ See Dreyer (2007), pp. 83, 93, 146, 155. Zheng He himself might not have been a member of the sub-group of ships that reached Africa on the seventh expedition.

${ }^{4}$ See Edward Said's foundational critique of Orientalism, with its "domestications of the exotic" and the "limited vocabulary and imagery that impose themselves as a consequence." In Orientalism, (copyright 1978, Vintage Books, 1979), p. 60.

5 See especially Timothy Brook (2010), pp. 93-94, and Dreyer (2007), p. 181. For a further discussion of Brook's attentiveness to the danger of using Western paradigms to describe Chinese events, see this article, below, pp. 12-14. Dreyer discusses two variants of Western narratives "within which ships and seafaring were major components of world history": 1) exploration/colonial expansion and 2) commercial interests protected by a nation's sea power (181-82). The model Dreyer follows most closely is Alfred Thayer Mahan's late-nineteenth century theory of a nation's commercial interests being protected by its fleets, and yet, Dreyer insists, "neither Zheng He nor the emperors he served ever had any theory of sea power of the sort made popular by the American admiral Alfred Thayer Mahan and other writers around the turn of the twentieth century" (3).
} 
He for English language scholars. Levathes argues that the Yongle emperor- the leader who authorized the first six of Zheng He's expeditions - wished to expand China's trade. In this, the Yongle emperor rejected his father's policies (88), policies that viewed “unrestricted private trade as inherently destabilizing and threatening" (123). Thus, in preparation for trading opportunities along its journey, the Chinese treasure fleet prepared for its first expedition by collecting silks, porcelain, and ironware ("nails, needles, pots, and iron wire") (84).

Levathes enriches her argument by pointing to the relationship between trade and cultural transformation, as when she reports the gift of ten aidai, or eyeglasses, to the Chinese emperor from Parameswara of Malacca, which, Levathes surmises, may have "marked the beginning of glass-making in China" (119). On this note, Levathes writes, "in the hulls of the treasure ships were the calendars, books, musical instruments, weights, and measures that in some small measure spread Chinese culture to every port the fleet touched" (186).

Levathes acknowledges the potential military power of Zheng He's enormous fleet, and in her telling, this power operated to support Chinese trade. When Levathes describes, for instance, the conflict between Zheng He and the pirate Chen Zuyi, the motivation she attributes to Zheng He is that he is making the Malacca Straits safe for commerce. Her Zheng He is relatively pacific, avoiding Chen Zuyi while making his journey outward from China (98) and only engaging in battle when the conflict becomes unavoidable (102). Levathes connects the reduced size of the second fleet to Zheng He's having disposed of Chen Zuyi on his first expedition: "The second expedition of the treasure ships had only sixty-eight ships, perhaps because some of the warships had been deemed unnecessary and left at home. With the pirate nest in Sumatra eliminated, the seas were certainly safer. Together, the two voyages had 
reestablished China's trade links in southeast Asia" (106). ${ }^{6}$ For Levathes, Zheng He's purpose is to nurture commerce, and the inclusion of warships in his fleet arises only from a need to defend the oceans for trade $(89,106)$.

Although Levathes initially rejects theories that point to Zheng He as diplomat (88), she does acknowledge the importance of the tributary system in understanding Chinese culture. She points to the many "tribute-bearing ambassadors" (118) who accompanied Zheng He on his return to China at the close of his expeditions $(102,103)$, even as her argument consistently connects "tribute and trade" (118, for example). In the chapter, "Emissaries of the Dragon Throne" (pp. 123-35), Levathes offers evidence of forms of power that stretch beyond the economic sphere: "The voyages of the treasure ships were among nearly fifty emissarial missions dispatched by the Yongle emperor during his twenty-four-year reign. They were but one part of a grander scheme to extend China's influence and power to the world's 'four corners"” (124). Levathes also acknowledges as "a dizzying display of diplomatic maneuvering" (124) the vast array of missions - to the Mongols, to Tibet and Korea, in addition to Zheng He's expeditions - undertaken by the Yongle emperor. Furthermore, in the chapter titled "The Last Voyage” (pp. 167-81), Levathes notes that the emperor who sent Zheng He on his seventh and final voyage, nearly a decade after the sixth voyage, "was concerned about the noticeable decline in China's tribute trade and what he perceived to be the loss of influence in the international community" (168).

\footnotetext{
${ }^{6}$ Dreyer and Levathes differ in their account of the number of ships on this second expedition: Dreyer argues that all of the expeditions were similar in size $(62-63,124-25)$, although there is no definitive record of the number of ships on the second expedition. Levathes does not offer her source for the sixty-eight ships she believes to have been on the second expedition. Furthermore, Levathes contends that Zheng He remained in China during the second expedition of the treasure ships, the expedition being led instead by Wang Jinghong and Hou Xian (103, 106). While conceding that "the evidence is inconclusive" (66) as to whether Zheng He led the second expedition, Dreyer leans toward the more recent scholarly view, based on Fei Xin's report, that Zheng He was indeed present $(65,72)$.
} 
In narrating Zheng He's last expedition, Levathes employs a vocabulary of tribute and power rather than of trade and wealth. Her choice of quotations from the Changle tablet (left by Zheng He in Fujian as he prepared to leave on his last voyage) details some of the goals of the Chinese tribute system:

In the Changle tablet, Zheng He proudly stated his belief that the expeditions of the treasure fleet "in unifying seas and continents" had far surpassed the maritime achievements of previous dynasties. ... In conferring presents on these distant peoples, Zheng He made it clear that he believed the expeditions also had an impact in spreading Chinese culture abroad, that is, in making "manifest the transforming power of imperial virtue." (170)

Levathes states that the emperor "was pleased with the results of the voyage. On September 14 [1433] the ambassadors of Sumatra, Ceylon, Calicut and Chine, Hormuz, Dhufar, Aden, and the other Arab states paid tribute at Fengtian Palace with horses, elephants, and a giraffe..." (172). Levathes continues: "It seemed as if Zhu Zhanji had accomplished his purpose in reestablishing the tribute trade with the Indian Ocean basin and making 'ten thousand countries our guests"' (173). Although her overall focus on Zheng He is on Chinese trade, Levathes does not ignore the Chinese tributary system.

Levathes's connection with Joseph Needham (Acknowledgments, 233) and her on-site investigation of Chinese routes and source material (Acknowledgments, 233-35) point to her serious scholarly contribution; through this contribution, her work has presaged an era of close attention to Zheng He in the English-speaking world. However, the paradigm that predominates in Levathes's book, that of Zheng He as enabling the Chinese to develop a trading empire, is closely related to popular notions that compare him to Columbus or da Gama. Levathes 
demonstrates her dependence on this comparative framework when she writes, "While Europe was still emerging from the Dark Ages, China, with her navy of giant junks, was poised to become the colonial power of the sixteenth century and tap the riches of the globe" (142). The implications tied to this comparison pose a temptation for many Westerners who study or teach Zheng He, and in his review of her book, Robert Finlay points these out:

[The question of why the voyages ended for good in 1433] has fascinated anyone acquainted with the voyages because of the counterfactual considerations it points to: What would have happened if China had continued to "rule the seas?" Would European powers have been able to create overseas empires in Asia? Would China (and not the West) have achieved world hegemony? On these broad questions, Levathes seems to idealize China's maritime imperialism, contrasting the relatively peaceful expeditions of "the treasure fleet" with the rapacity and oppression which Portuguese ships brought to Asian waters. Behind this contrast stands the larger one of a self-sufficient Celestial Kingdom and a congeries of European powers avid for the riches of the East. (321-22) Nonetheless, in spite of the concerns I raise here, Levathes's book is to be praised for presenting Zheng He to a broadly based English-speaking audience.

\section{Zheng He as Explorer}

If Levathes's reading of Zheng He is tied to a Western understanding of early modern trade, Gavin Menzies's reading of Zheng He, in 1421: The Year China Discovered America (2002), relies upon the Western paradigm of exploration. Menzies is a controversial best-selling writer, and given that scholars have resoundingly debunked his theories, ${ }^{7}$ it might seem odd that I include his work in this analysis of scholarship on Zheng He. The value for this article is the

\footnotetext{
${ }^{7}$ See the Wikipedia entry, "Gavin Menzies" (accessed 10 June 2019), for a preliminary list of scholars who have refuted Menzies' claims.
} 
way Menzies' writing exemplifies one widespread assumption about how to think about Zheng He's travels. From the beginning to the end of his book, Menzies's primary vocabulary is that of exploration: "great voyages of exploration" (67), "voyages of discovery" (69), "Chinese voyages of discovery" (442), "fifteenth-century Chinese explorers" (448), and "great Chinese voyages of exploration" (473) is the terminology that dominates this book.

Menzies approaches his writing through his own experience of a career serving in the British Royal Navy (35). His introduction cites his curiosity about Zheng He having been piqued by his study of a 1424 map signed by the Venetian Zuane Pizzigano (29). The primary lens through which he sees Zheng He's expeditions is that of having been a navigator (36) and Menzies focuses much of his argument on one navigational goal he claims the Chinese achieved during their expeditions: developing a method of assessing longitude. Early in his book, Menzies teases readers with an implied promise of what the end of the book will argue, with claims that "a method of calculating longitude" would not be "perfected until near the end of their [Zheng He's] voyages" (93). Much of Menzies's analysis of Zheng He's later voyages follows his search for proof of the Chinese having sought—and achieved — this navigational goal. Unfortunately, much of Menzies's analysis rides on suppositious reasoning, as even Menzies himself admits: "To date there is no connection between the Chinese and the calculation of longitude. All we can say is that an accurate calculation of longitude had been achieved before 1502 when the Cantino [map] arrived in Italy" (367-68).

Menzies might seem to redeem his reliance on Western paradigms as normative through some of his comparisons between East and West where he finds China to be far more advanced than the West. He argues that Chinese libraries of the fifteenth century were superior to those of the west: "a massive encyclopedia of four thousand volumes . . . was completed just before the 
Forbidden City was inaugurated. ... There was nothing remotely comparable anywhere in the world... . [T]hough Europe was on the eve of the Renaissance that was to transform its culture and scientific knowledge, it lagged far behind China" (62). Likewise, Chinese court life leaves Europe appearing "backward, crude and barbaric" (63):

Henry V's marriage to Catherine of Valois took place in London just three weeks after the inauguration of the Forbidden City. Twenty-six thousand guests were entertained in Beijing, where they ate a ten-course banquet served on dishes of the finest porcelain; a mere six hundred guests attended Henry's nuptials and they were served stockfish (salted cod) on rounds of stale bread that acted as plates. (63)

Chinese scientific investigation (69) and Chinese naval power (70) are similarly compared to those of the West, with the West in each case found lacking. As he concludes, Menzies critiques Western colonialism, "Instead of the cultured Chinese, instructed to 'treat distant people with kindness', it was the cruel, almost barbaric Christians who were the colonizers" (454). While the Chinese achievements that Menzies lists are indeed noteworthy, consistently listing them in comparison to the West risks rendering the value of Chinese culture limited to those ways in which such comparisons can be drawn.

As Levathes does, Menzies acknowledges the Chinese tributary system as one way of describing Chinese maritime expeditions $(60,64)$. Menzies paraphrases the Ming understanding of the expeditions, as proclaimed by the two 1431 stone carvings left by Zheng He, in this way: "The mission was to 'proceed all the way to the end of the earth to collect tribute from the barbarians beyond the seas ... to attract all under heaven to be civilised [sic] in Confucian harmony"' (64). Relying on the same source material (the 1431 stone carvings), Menzies repeats a very similar argument later in his book: "Zhu Di's master plan to discover and chart the entire 
world, and bring it into Confucian harmony through trade and foreign policy, could have succeeded, for the whole world now lay at China's feet - or so it must have seemed to his admirals when the handful of surviving ships of the treasure fleets limped home during the autumn of 1423" (453-54). However, neither Levathes nor Menzies focuses on the tributary system as the primary way for their readers to understand the Chinese motivation for creating and sending forth Zheng He's fleets.

\section{Zheng He and Power Held by Ming-Dynasty Eunuchs}

One history of the Ming Dynasty that, without focusing specifically on Zheng He, offers the English-speaking scholar an important context for a reading of Zheng He's voyages, is The Eunuchs in the Ming Dynasty (1996), by Shih-shan Henry Tsai. Tsai reads Zheng He's expeditions within the context of the Ming Dynasty's "grand design to incorporate all the neighboring states into its tributary system" (141). Although Tsai's book has only a short section that focuses specifically on Zheng He's life and expeditions, ${ }^{8}$ his argument, that Zheng He's voyages need to be understood within the context of other "eunuch-led missions" of the era (153), is important for the purposes of this paper.

As the title of his book conveys, Tsai argues that important contributions made by eunuchs to Chinese history and culture have long been overlooked. Tsai finds it problematic that historians of Ming China have followed the lead of the Confucian scholars and literati who recorded the earliest official histories of the era-Confucian scholars who wrote of the achievements of their own "coterie of scholar-officials" and "simply cut eunuchs out of the loop" (140). "Orthodox Chinese historians almost universally attribute the downfall of the Ming dynasty to the lascivious conduct and the insolent power of the eunuchs" (26), Tsai writes, in

\footnotetext{
8 “Zheng He's Seven Navigations”, pp. 153-64 in Chapter VII, “Eunuchs and Ming Maritime Activities,” pp. 141-64.
} 
explanation of his own scholarship as a corrective to this trend. Thus, Tsai's careful scholarship notes eunuch participation and leadership in many areas of Ming society, from military to diplomatic, from economic to judicial; Zheng He's leadership is but one contribution among many that eunuchs provided the Ming Dynasty.

\section{Zheng He and the Chinese Tributary System}

Edward Dreyer's Zheng He: China and the Oceans in the Early Ming Dynasty: 14051433 (2007) is an English-language book-length study of Zheng He that relies on the Chinese tributary system as its primary paradigm for understanding the Ming Dynasty voyages. Dreyer reads Zheng He's expeditions not as voyages of exploration but as "power projection" (xii). Dreyer writes, "the purpose of the voyages was not primarily exploration but showing the flag and establishing a Chinese armed naval presence on familiar trade routes and trade entrepôts" (79). In contradiction to any portrait that portrays a pacific Zheng He, Dreyer argues,

Zheng He's voyages were undertaken to force the states of Southeast Asia and the Indian Ocean to acknowledge the power and majesty of Ming China and its emperor. This objective required a much greater naval presence than any amount of exploration would have needed. Zheng He's armada was frightening enough that it seldom needed to fight, but being able to fight was its primary mission. (xii)

Dreyer argues that the "virtual cessation of diplomatic activity after 1422" points to the diplomatic importance of Zheng He's missions: "the overwhelming military power represented by Zheng He's fleet—the Xiafan Guanjun, or Foreign Expeditionary Armada—was the key to maintaining the kind of diplomatic relationships that Emperor Yongle, at least, wanted to have with the countries of Southeast Asia and the Indian Ocean" (144). 
For Dreyer, any trade that takes place on or as a result of Zheng He's expeditions is secondary to the expression of power they display. Contra Levathes, Dreyer argues, "Yongle shared his father's suspicions about trade by privately owned Chinese ships, and he never relaxed his father's ban on foreign trade by Chinese merchants" (62). ${ }^{9}$ While acknowledging that the fleet's "carrying capacity ensured that by itself it could add significantly to the volume of trade" (84), Dreyer argues that "the sources dwell on the diplomatic aspects (and, to a lesser extent, the "power projection" aspects) of the voyages" (84). Dreyer also notes what he calls the "fundamental enigma" of the Zheng He voyages: "while prohibiting foreign trade by his own subjects, the emperor nonetheless wished to display Chinese power to foreign countries whose own wealth was gained from such trade" (79). For Dreyer, Chinese expression of power can include but is not focused on trade.

Instead of defining Chinese maritime expeditions through what we know about the rise of trade and exploration in the West, Dreyer emphasizes the contrasts between the two to better define the Chinese expeditions: "The goal of the Chinese voyages had been to force the maritime countries they visited into compliance with the norms of the Chinese tribute system of foreign relations; the more radical Portuguese goal was to force the spice trade away from its traditional Red Sea and Persian Gulf routes and onto a route around Africa that the Portuguese would control" (176). Implicit in this contextualization is Dreyer's rejection of the trade and exploration theses which guide Levathes's and Menzies's accounts: for Dreyer, an understanding of the Chinese tributary system is crucial to an understanding of Zheng He's voyages.

Dreyer's book lacks the scholarly footnotes that would greatly support the careful reader's assessment of his argument. However, he does reference, throughout his book, the various sources that he uses as source material. He frequently notes the different and sometimes

\footnotetext{
${ }^{9}$ Cf. Dreyer 39-41 on the Hongwu emperor's suspicion of private trade.
} 
contrasting details provided by Ma Huan, Fei Xin, and the Mingshi, as, for example, when he assesses Zheng He's fifth voyage (89). At the close of his book, he provides a brief "Note on the Sources" (217-22) which serves as a very useful annotated bibliography. Importantly, he explains his rejection of the 1597 Luo Maodeng novel, Sanbao Taijian Xia Xiyang Ji Tongsu Yanyi (usually cited as the Xiyang $\mathrm{Ji}$ ) as a reliable historical source. And most importantly for those teaching Zheng He to students not fluent in Chinese, Dreyer provides original translations of three important primary source materials: the Mingshi Biography of Zheng He and the two 1431 stones engraved with accounts of Zheng He's journeys (Appendices 1-3, pp. 187-99).

For Timothy Brook in The Troubled Empire: China in the Yuan and Ming Dynasties (2010), the Chinese tributary system provides the best context for understanding Zheng He's voyages. Brook explains the tributary system as "a device for mutual recognition and mutual legitimation that propped up China's claim to world hegemony" (219) and elaborates: "The tribute system required foreign rulers to send embassies to China bearing tribute in the form of local exotica. The emperor in turn presented these emissaries with gifts of equal or greater value, which they took back to their rulers. The emperor also bestowed titles on tributary rulers, and might even name his favorite in a succession dispute" (219). Brook not only defines the tributary system for his readers, he also explains the Yongle emperor's particular motivation for engaging in the symbols of power derived from Zheng He's voyages: the emperor needed to prove the legitimacy of his reign after having seized power from his nephew.

The stench of illegitimacy being strong, Yongle had to mobilize every device he could think of to mask it. One was to move the capital from Nanjing to Beijing. . . . Another was to announce to the maritime world, as Khubilai had done, that he was now emperor. 
This he did by dispatching a series of trusted military eunuchs at the head of diplomatic missions to tributary states around Southeast Asia. Best known of these is the Muslim eunuch who led six of these missions, Zheng He (1371-1433). (93, my italics $)^{10}$ Thus, Brook's emphasis on the Chinese tributary system as the most important context for understanding Zheng He is true not only for Chinese history and culture in general, but for the particularities of time and place for Zheng He and the Yongle emperor.

Brook offers a vital corrective for those tempted to understand Zheng He through comparison to Columbus. He begins by refuting the traditional Western understanding of Columbus: "Columbus was not an explorer. His voyages were vehicles of speculative commercial investment aimed at establishing direct trade links with China .... [The Spanish] interest in the voyages was principally financial, not diplomatic or political or intellectual" (94). With this importantly relocated definition of Columbus, Brook argues that Zheng He's expeditions arose from an entirely different cultural milieu than did those of Columbus, and the details of Brook's argument justify quoting him at some length:

When Columbus is viewed this way (rather than as the heroic explorer who "discovered" the Americas and changed the world), Zheng He begins to emerge from the mist of misrecognition as more his opposite than his avatar. Zheng's purpose was diplomatic: a mission to declare to all tributary states known to China that Yongle was now the emperor and that they should send him tribute to acknowledge the fact. He took with him

\footnotetext{
${ }^{10}$ Regarding the "stench of illegitimacy," of Yongli's claim to power, Brook writes, "Fang Xiaoru was but one of many court officials who would pay dearly for choosing loyalty to the dynasty over subservience to the man who happened to hold power at any one moment in time. Fang was not the only victim of what Yongle termed his "pacification of the south." The coup was followed by the execution of tens of thousands in a bloodbath that rivaled the worst of his father's purges. A second founder in the mold of the first was on the throne. The autocratic turn in Chinese politics has been laid at the feet of the Mongol emperors who ruled Yuan China, yet emperors Hongwu and Yongle were decisive in hollowing out the core Confucian values of obligation and reciprocity that the Ming regime might have nurtured in the restoration of the old imperial system." (92).
} 
a sizeable military force to make sure that the rulers on whom he called did not refuse his command, but he was not intent on conquest. China had an interest in lubricating commercial links throughout maritime Asia, and its fleets helped Chinese merchants to enlarge their trade circuits, but the voyages were not targets of investment. Nor were they expected to produce the stunning returns in gold that Columbus promised, and consistently failed to deliver, to Ferdinand and Isabella. Finally, Zheng's ships did reach places to which no Chinese officials had ever traveled, notably on the east coast of Africa, but they were sailing known routes that Muslim traders in the Indian Ocean had long been using. Chinese mariners may have been unfamiliar with some of these places, but they were not in any sense "discovering" them. They were simply adding them to the roster of states that should acknowledge Ming suzerainty. Zheng He was not an explorerentrepreneur out on the ocean to discover the world; he was an imperial servant sent to get the one thing that his usurper-emperor craved: diplomatic recognition. This was political theater, and no less important for being so. (94) Diplomacy vs. conquest; moderate commercial "lubrication" vs. stunning financial speculation; exploration vs. following known routes — on each of these levels, Brook argues, the differences between Zheng He and Columbus must be recognized in order that a solid understanding of Chinese history can be achieved.

Not only does Brook explain why a comparison to the West is inadequate for explaining Zheng He, he actually flips the usual comparison on its head. Brook points out that for some time, Western explorers could have taken the opportunity to use Zheng He as a model for their own voyages: 
The Zheng expeditions were still remembered around the Indian Ocean when the Portuguese arrived. ... The Portuguese were curious to hear that "white-skinned" foreigners - which is how South Asians remembered the Chinese — had once visited all the major ports around the Indian Ocean. As their ambitions in Asia grew, some looked to Zheng He as a model, whether that model was the wisdom of refusing to seize colonial possessions, as some praised Zheng for having done, or the institution of accepting tribute from port states willing to trade with the Portuguese. (225-26, italics mine) However, in their encounters with potential trading partners in the Indian Ocean, the Portuguese clung to their own notions of how to interact with other cultures: "The Portuguese arrival in 1511 at Malacca at the western edge of the South China Sea was violent. When they discovered a Chinese commercial community already based there and handling a brisk trade, they decided to treat them as their main competitors and do what European traders as a general practice did to their competitors: kill them and take over their business" (226). Brook's history of Ming China provides a thoughtful and well-documented context for an understanding of Zheng He within the context of fifteenth-century Chinese culture and politics, and an important counter-point to those tempted to define Zheng He simply through Western paradigms.

\section{Chinese Responses to Zheng He}

Westerners are not the only shapers of popular opinion to structure an analysis of Zheng He through comparison to the West. Chinese scholarship on all details of Zheng He's life has exploded in the past century, and some of it, too, has been shaped by comparison to the West. Although a detailed assessment of Chinese resources on Zheng He is beyond the scope of this paper, the 1905 essay by Liang Qichao, "Zheng He: A Great Navigator of Our Mother Country," is important to note as it is foundational in the tone it set for many twentieth-century 
discussions. ${ }^{11}$ As Edward Dreyer explains, "Liang Qichao was a major player in the earlytwentieth-century debates about how and to what extent China needed to Westernize; not knowing much about Zheng He, his approach was to compare him to Columbus as an explorer" (181). In this vein, Kuei-Sheng Chang's entire essay (1974) is shaped by such a comparison, organized around the question, "what were the circumstances that hindered the Chinese from sailing into the Atlantic or circumnavigating Africa"-in contrast to the "epoch-making feats of the daring Portuguese captains which ushered in a new era in maritime history" (347). Assessments of the structure and size of Zheng He's ships, the number of ships in his fleet, the number of personnel on the ships, his geographical knowledge and navigational abilities, and the motivation for his expeditions have all been compared to similar factors in the West. ${ }^{12}$ Popular culture likewise points to the ways that Chinese shipbuilding of the Ming era surpassed Western capabilities, as evidenced by a remarkable image, no longer present, in a 2008 Wikipedia article on Zheng He: a photo of a three-dimensional model, in the Ibn Battuta Mall in Dubai, of one of Zheng He's ships, standing side-by-side with a model of one of Columbus's much smaller ships:

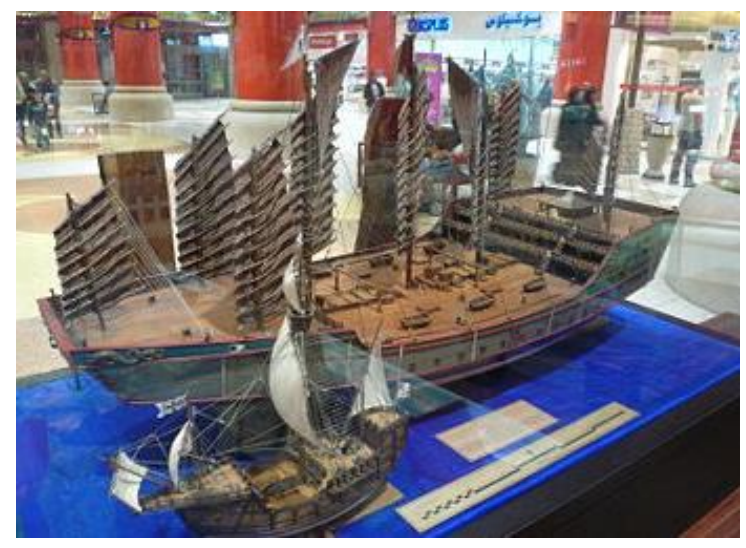

\footnotetext{
${ }^{11}$ Published in the journal Xinmin Congbao; title translated in Dreyer, p. 181. An alternate translation of this influential article is "Zheng He, A Great Chinese Voyager" or "Zuguo da hanghaiji Zheng He zhuan," Xinmin congbao 3.21:1905, cited in Wan Ming (2004), p. 17.

${ }^{12}$ See the chart in Yamashita (2006), p. 27.
} 
Much of the Chinese effort in drawing comparisons to the West involves shaping a strong-but-peaceful image of China. This is the angle of the comparison drawn by Wan Ming, who writes, "the peaceful and stable model of Chinese maritime expeditions contrasted sharply with the Western model dominated by violence and plundering (27). In 2005, Wan Ming was quoted in the New York Times in this regard: "In the heyday of the Ming Dynasty, China did not seek hegemony....Today, we are once again growing stronger all the time, and China's style of peaceful development has been welcomed all over the world." 13 Similarly, the International Zheng He Society of Singapore promotes a Zheng He whose "contributions changed the face of the region for a more peaceful and prosperous world"; in response, the Society has taken as its goal the promotion of "scholarly research on Zheng He's enduring contribution to peace, good will, and ethnic and cross-cultural understanding among nations." ${ }^{14}$ However, even as such a comparison promotes a positive image of a pacific China, the terms remain dictated by an implicit understanding of the Western tradition as primary.

Other images of Zheng He remain important to remember as counterweights to the Western paradigms. The 1597 novel by Luo Maodeng, for example, may not serve as a reliable source for historical detail about Zheng He's expeditions, but it offers a clear example from the late sixteenth century of a Chinese desire to glorify Chinese strength on the seas (Dreyer 177). The Chinese Confucian administrators - those who from the beginning declared Zheng He's expeditions too expensive to sustain — provide another example of promoting a particular image, an image originating from Chinese traditions, of Zheng He. The Confucian historians judged Zheng He from the perspective of administrators and educators whose authority was threatened by an alternative source of power. In fact, some of today's scholarly questions about Zheng He's

\footnotetext{
${ }^{13}$ Quoted in Joseph Kahn (2005.

${ }^{14}$ Unnumbered page facing title page, in Hum Sin Hoon (2012).
} 
expeditions arise because of the destruction of documentation, destruction that probably took place in 1480, at the hands of Liu Daxia, a government administrator who feared the power of the eunuchs to drive Chinese emperors into renewed military engagement. ${ }^{15}$

\section{Teaching Zheng He in a Liberal Arts Context}

What does this summary of various understandings of Zheng He have to do with best practices in infusing Asian Studies materials into a Liberal Arts General Education curriculum? My primary argument, that it is tempting to write (and teach) Zheng He within the context of familiar Western traditions, points to the need to develop practices to stretch beyond Western paradigms. Three elements are important to keep in mind in seeking to implement best practices in teaching: 1) including primary texts/ primary voices from the time; 2) providing multiple contexts for the materials and encouraging students' critical thinking about those contexts; 3) openly admitting to students the challenges of applying best practices and asking them to join in the process of discernment for further improvement.

When teaching the Ming Dynasty in a General Education Core Class, I open my class with a short excerpt from Yang Deze in the 1993 collection, Voices from the Ming-Qing Cataclysm: China in Tigers'Jaws_-“There Was Only Me”: A Boy Eunuch Sees the Bitter End"- and I close the course unit on the Ming Dynasty with a discussion of the short story by Ling Meng-ch'u, "Wine within Wine . . Craft within Craft." Although neither I nor my students are qualified to work with Chinese texts in their original language, these short readings enable students to engage with texts that introduce vocabulary, customs, mindsets and cultural critiques from the Ming Dynasty. Similarly, the primary source materials translated by Dreyer can provide an introduction specific to Zheng He, particularly if these are assigned together with pointed

\footnotetext{
${ }^{15}$ See Levathes 179 and Dreyer 173-74 for their assessments of the various seventeenth-century Chinese documents that discuss the disappearance of reports on Zheng He's expeditions.
} 
questions students can respond to through the course of their reading. "What does the Mingshi state are the goals of Zheng He's journeys?" "How do the Mingshi and the two stone inscriptions provide explanations for the exercise of military power on Zheng He's journeys?" "What sense of 'other' (that is, non-Chinese) do we get from reading these primary materials - that is, how do the writers imagine the Chinese relationship with those of other lands?" These are some of the questions that can engage students with these brief readings.

The examination of context is key to historical study, and helping students understand a variety of available contexts that can lead to different questions (and therefore to different answers, and different kinds of answers) is one method of helping students develop critical thinking skills. A presentation of the various lenses of the authors discussed in this essay can be accomplished either briefly or in some detail, depending on the course goals and structure. A quick look at context could present Zheng He as trader, explorer, or leader of Chinese tribute missions, and could ask students to consider the implications of each interpretive lens. A more lengthy discussion could be introduced by assigning brief readings from Levathes, Menzies, Tsai, Dreyer and Brook, and asking students to assess for themselves the primary interpretive lens of each author, again closing with a discussion of the impact of each lens. Ideally, the introduction of Tsai, Dreyer and Brook, and the opportunity to learn about the Chinese tributary system, can enable students in identifying and questioning the Eurocentric nature of the trader/explorer paradigms.

My own work introducing Zheng He to students began in a Western Cultural Heritage course. This course, by definition, was shaped to focus on the Western tradition, and therefore worked with Asian studies on a comparative basis that did not place the two on equal footing. As Jack Goldstone has argued, the traditional Western Cultural Heritage program, even when 
introducing content and context on Asian or other cultural traditions, is based on a story line that favors the West:

At present, the major theme of world history from the beginning of the Near Eastern fertile crescent civilizations is the rise of the West. This is told as dominated by a series of rises and falls in which the "West" always advances. ... Other civilizations feature in this story mainly as passive recipients of European trade and conquest, and as oddly unimaginative bestowers of great inventions - stirrups, gunpowder, the compass, the sternpost rudder, paper and printing — whose potential was only realized in European hands.

In response to this curricular challenge, I strive to help students interrogate the comparisons we draw in our studies. Thus, when a discussion of the Scientific Revolution in the West allows me to present scientific achievements in China, or a class period on Western "Contact and Conquest" allows me to introduce Zheng He, I ask my students to critique the very act of drawing such comparisons. When comparing scientific developments, I point out to students that by studying the early modern era in Europe, and by focusing on Galileo, my syllabus design influences the questions - and the answers - we use to make our comparisons. We discuss and critique the things we might learn through various ways that one might discuss "science" in East and West, from comparing the development of specific technologies (gunpowder? printing?), to choosing an era for drawing the comparison. While study of the scientific revolution of the early modern era might seem to favor the West, a comparison of East and West in the tenth through thirteenth centuries would draw a very different conclusion about scientific developments during the Song Dynasty. For most of my students, the college-level study of Western history and philosophy already introduces a level of cultural engagement new to them; the study of Chinese cultural 
developments is even more unfamiliar. They are excited to engage with this material, with its introduction of fresh texts, cultures, and contexts. I encourage that excitement, yet I also encourage my students to be critical of the ways we engage with the material.

The kinds of issues I've raised here so far involve assignment design, classroom engagement, and course design, but when seeking to avoid Eurocentrism in our academic engagement, we need to think about these issues on a curricular level as well. Institutions that seek to promote global engagement in their students need to inquire how best to include in their core studies the diversity of content they want to engage. This means entering into conversations about core studies, including whether the study of Western Cultural Heritage remains the most relevant set of core materials for students planning to enter a global society. Conversation about designing a core curriculum that includes Asian studies in their own right, and not merely in comparison to Western texts, has recently been raised at a conference at the Liberal Arts Institute at Concordia University (Irvine, California; July, 2018), titled "Global General Education and Asian Texts: What Should Students Read?” Conversation needs to continue regarding not just what texts students should read, but how those texts are presented.

The process of infusing materials from Asian Studies into a Western Liberal Arts curriculum requires many steps and ongoing critical attention. As my friends from the Infusing Institute at the Asian Studies Development Program have pointed out, the first step is to find ways that materials can be infused - that is, to get the conversation started. Yet it is vital to remember as well that this first step is the opening of a conversation, and that this newly opened door demands further attention to thoughtful cultural engagement. Attention to context and work with primary sources provide important methodological components for teaching. A posture of humility about seeking best practices remains important for both student and professor. 


\section{Works Cited}

Brook, Timothy. (2010). Troubled Empire: China in the Yuan and Ming Dynasties. The Belknap Press of Harvard University Press.

Chang Kuei-Sheng. (1974). The Maritime Scene in China at the Dawn of Great European Discoveries. Journal of the American Oriental Society, 94 (3), 347-359. http://www.jstor.org/stable/600069

Dreyer, Edward L. (2007). Zheng He: China and the Oceans in the Early Ming Dynasty: 14051433, The Library of World Biography, series editor Peter N. Stearns. Pearson Longman.

Finley, Robert. (1997). Book Review of Louise Levathes, When China Ruled the Seas: The Treasure Fleet of the Dragon Throne, 1405-1433. Sixteenth Century Journal 28 (1), 32123. https://www.jstor.org/stable/2543313.

“Gavin Menzies.” Wikipedia. Accessed 10 June 2019.

Goldstone, Jack. (2001). The Rise of the West - or Not? A Revision to Socio-economic History. University of California, Davis. http://www.hartford-hwp.com/archives/10/114.html Accessed 11 July 2018.

Green, John. (2012). Crash Course: World History \#21, Columbus, da Gama and Zheng He! $15^{\text {th }}$ Century Mariners. https://nerdfighteria.info/v/NjEGncridoQ/ Accessed 19 July 2018.

Hoon Hum Sin. (2012). Zheng He's Art of Collaboration: Understanding the Legendary Chinese Admiral from a Management Perspective, Institute of Southeast Asian Studies Singapore and International Zheng He Society.

Kahn, Joseph. (2005). China Has an Ancient Mariner to Tell You About. New York Times. https://www.nytimes.com/2005/07/20/world/asia/china-has-an-ancient-mariner-to-tellyou-about.html Accessed 11 July 2018.

Levathes, Louise. (1994). When China Ruled the Seas: The Treasure Fleet of the Dragon Throne, 1405-1433. Oxford University Press.

Ling Meng-ch'u. (1994). "Wine within Wine .. . Craft within Craft . .." Translated in Victor H. Mair (ed.), The Columbia Anthology of Traditional Chinese Literature (pp. 909-933). Columbia University Press.

Menzies, Gavin. (2002). 1421: The Year China Discovered America. Harper Perennial, 2003; first published by Transworld Publishers, 2002.

Said, Edward. (1979). Orientalism. Vintage Books. 
Tsai Shih-shan, Henry. (1996). The Eunuchs in the Ming Dynasty. State University of New York Press.

Wan Ming. (2004). Reflections on the Study of Zheng He's Expeditions. Ming Studies. https://doi.org/10.1179\%2F014703704788762899

Yamashita, Michael. (2006). Zheng He: Tracing the Epic Voyages of China's Greatest Explorer. Vercelli, Italy: White Star Publishers.

Yang Deze. (1993). “"There Was Only Me’: A Boy Eunuch Sees the Bitter End.” In Lynn A. Struve (Ed. and Trans.), Voices from the Ming-Qing Cataclysm: China in Tigers' Jaws. (pp. 239-60). Yale University Press.

“Zheng He.” Wikipedia. Accessed September 2008. 